\title{
Sexualidade humana: educação libertadora para o amor Reflexões ético-teológicas mediadas pela Práxis Educacional de Paulo Freire a serviço de uma pastoral comprometida com a vivência humanizada da dimensão afetivo-sexual
}

\author{
Orientador: Alfonso Garcia Rubio \\ Mestrando: Cássia Quelho Tavares \\ Área de Concentração: Teologia Sistemático-Pastoral \\ Linha de Pesquisa: Religião e Modernidade
}

Esta tese resulta da preocupação da autora com significativa experiência profissional na área da saúde da mulher e efetiva presença na pastoral em torno do tema da sexualidade humana. Busca apresentar uma metodologia de educação continuada visando a formação da pessoa na pastoral para melhor compreensão e vivência de sua dimensão afetivo-sexual. No primeiro momento, apresenta o ser humano na sociedade contemporânea na sua forma de compreender e viver a sexualidade, influenciado por diversas situações antropológicas, sociais, culturais, que nem sempre favorecem o desenvolvimento harmonioso da dimensão afetivo-sexual, mas que interferem em seu pensar e agir. Quer enfatizar, ainda, a reflexão que a contemporaneidade exige dos cristãos e teólogos sobre a necessidade de um empenho contínuo na construção de um saber integrador e interdisciplinar que contribuam para o amadurecimento da pessoa em todas as suas dimensões. Apesar dos recorrentes "prejuízos", no campo da sexualidade, em virtude de uma visão dualista do ser humano, existe a possibilidade de mudanças iniciada na moral renovada no pós-concílio do Vaticano II com a importante contribuição de documentos da Igreja sobre a Ética Sexual. A autora aponta lacunas e deficiências nas formas de abordagem do tema afetivo-sexual no trabalho teológico acadêmico e na atuação pastoral. 
Propõe uma metodologia, alicerçada na reflexão ético-teológica, mediada pela Práxis Educacional de Paulo Freire, para uma Educação Continuada, libertadora e humanizadora, a serviço da pessoa na pastoral, para o seu desenvolvimento e amadurecimento afetivo-sexual.

Palavras-chave: Sexualidade Humana; Sociedade Contemporânea; Ética Sexual Cristã; Antropologia Integrada; Paulo Freire. 